\title{
Blessed Are the Peacemakers: The Contribution of Christian Nonviolence to Anarchism
}

Sam Underwood

Memorial University of Newfoundland

Although Christian anarchists are typically committed to pacifism, in the broader anarchist literature pacifism is a decidedly minoritarian position. It may be argued on this basis that Christian anarchists are pacifists on account of their Christianity rather than their anarchism, and that non-Christian anarchists, in not sharing Christians' commitment to following Jesus, have no similar reason to accept pacifism. However, this paper argues that the radical nonviolence defended by Christian anarchists is as consistently anarchist as it is Christian, for in Christian nonviolence we find anarchistic commitments to mutual aid, prefiguration, and attention to 'the least of these'. The paper therefore also suggests that the criticisms of violence articulated by Christian anarchists might actually speak to non-Christian anarchists too, and that nonviolence is in fact a central element of anarchist prefiguration.

What contribution can Jesus and his followers, especially those followers of Jesus who call themselves anarchists and pacifists, make to anarchist discussions of nonviolence? Is the position of radical nonviolence that is typically adopted by Christian anarchists simply a requirement of their being Christian, rather than having anything to do with their also happening to be anarchists? If so, then Jesus and his followers would have no contribution to make to anarchist discussions of nonviolence. On the other hand, if part of that which is seen in the teachings of Jesus as anarchistic by these Christian anarchists is precisely his radical nonviolence,

How to cite this book chapter:

Underwood, S. 20I8. Blessed Are the Peacemakers: The Contribution of Christian Nonviolence to Anarchism. In: Christoyannopoulos, A. and Adams, M. S. (eds.) Essays in Anarchism and Religion: Volume II. Pp. I96-23I. Stockholm: Stockholm University Press. DOI: https://doi.org/Io.I6993/bas.g. License: CC-BY. 
there may in fact be a connection between Christianity, anarchism, and nonviolence. In the present paper, I will argue for this connection. Specifically, I will argue that the biblically based argument for nonviolence - drawing primarily on the teachings of Jesus - is ultimately an anarchist case for nonviolence, insofar as it is consistent with anarchist calls to rethink normativity and fulfils the prefigurative principle, and, as such, deserves serious consideration by both Christian and non-Christian anarchists.

Before proceeding, I should say something about how I am using the present volume's guiding terms, 'religion' and 'anarchism.' As the editors note in the introduction, both terms are quite difficult, if not impossible, to define in such a way that leaves no room for objection. Without attempting to offer exhaustive or wholly non-problematic definitions, then, I will simply indicate what I have in mind when I employ these terms.

Regarding 'religion,' my own inclination is to call 'religious' those traditions, texts, beliefs, and practices which attempt to say something about and/or foster communion with the 'divine,' 'sacred,' or 'transcendent.' ' And I understand 'anarchism' to be a political philosophy which brings together radical anti-authoritarianism and radical egalitarianism. ${ }^{2}$ More specifically, in Peter Kropotkin's words, anarchism is "the no-government system of socialism," which seeks to maximize what Emma Goldman calls the "twin forces" of "individual liberty and economic equality," 4 through the

I Of course, these last three terms are themselves so broad and indefinite as to admit of a multitude of interpretations, but it seems that the phenomenon of religion is itself so marked by a multitude of interpretations that this difficulty is not only unavoidable but instead a defining feature of religion.

2 I am indebted to my friend and former teacher, Nathan Jun, for this articulation of the essential formula for anarchism. For a fuller discussion of this issue, see Nathan J. Jun, Anarchism and Political Modernity (New York: Continuum, 20I2).

3 Peter Kropotkin, "Anarchist Communism: Its Basis and Principles," in Anarchism: A Collection of Revolutionary Writings, edited by Roger N. Baldwin, (Mineola: Dover Publications, Inc., 2002) 46.

4 Emma Goldman, Anarchism and Other Essays (Second, Revised Edition), (New York/London: Mother Earth Publishing Association, I9I I), available from https://theanarchistlibrary.org/library/emma-goldman-anarchismand-other-essays\#toc4. 
dismantling of hierarchical structures of power and the reorganization of society along non-hierarchical, democratic lines. ${ }^{5}$

\section{Christian Nonviolence}

The case for Christian nonviolence is a familiar one: Jesus blesses the peacemakers, ${ }^{6}$ warns that those who live by the sword die by the sword, 7 and overturns lex talionis - "an eye for an eye" instead teaching nonviolent resistance. ${ }^{8}$ This final point is particularly important and is made by appealing to a proper translation of the Greek verb that Jesus uses for "resist." Walter Wink, for example, argues in Jesus and Nonviolence, that the verb is most accurately understood to refer to "violent rebellion, armed revolt, sharp dissention."9 "Support for this [Wink's] translation," writes Kurt Willems, "is not unwarranted as antistenai is the word repeatedly used in the Greek version of the Hebrew Bible as 'warfare' and is also used in Ephesians 6:I3 in the context of active military imagery." ${ }_{\text {Io }}$

Jesus exemplified nonviolent resistance in his life and teaching. For although he never violently aggressed another person - even to the point of not resisting his executioners - Jesus was, in John Howard Yoder's words, "a social critic and an agitator." "I And Bart Ehrman points out that in the empire, "only two known people were specifically called 'the son of God.' The emperor was one

5 Beyond this, several different visions have been proposed for what specific form such a society should take, including mutualist, communist, and syndicalist forms of organization. For an overview of these differences, see Ruth Kinna, Anarchism: A Beginner's Guide, (Oxford: Oneworld Publications, 2005).

${ }^{6}$ Matthew 5:9 (NRSV).

7 Matthew 26:52.

${ }^{8}$ Matthew 8:38-39.

9 Walter Wink, Jesus and Nonviolence: A Third Way, (Minneapolis: Fortress Press, 2003), I3.

ro Kurt Willems, "Nonviolence Ior - Resistance is Futile... or the Meaning of $\dot{\alpha} v \tau \imath \sigma \tau \tilde{\eta} v \alpha \imath$ (part 2)," available from http://www.patheos.com/blogs/ thepangeablog/20I I/O2/07/nonviolence-IOI-resistance-is-futile-or-the-

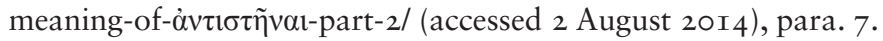

II John Howard Yoder, The Politics of Jesus ( $2^{\text {nd }}$. Ed.), (Grand Rapids: Wm. B. Eerdmans Publishing Co., I994), I. 
of them, and Jesus was the other." ${ }^{\text {I2 }}$ Jesus was boldly proclaiming the coming kingdom of God, of which he (Jesus) would be the king. It does not get much more subversive than that. "This was the message he delivered to his disciples," writes Ehrman, "and in the end, it was the message that got him crucified." "I3 Jesus was not passive or a quietist or an apolitical teacher of private religious morality. He was a nonviolent revolutionary.

This same line of argument is taken up by Christian anarchists, who argue that, as Alexandre Christoyannopoulos writes, because "The state is founded on the very thing Jesus prohibits" ${ }^{44}$ - namely violence - the state too must be rejected by Christians as immoral. The most obvious Christian objections raised against this position are the "render unto Caesar" passage, Jesus' cleansing of the temple, Jesus' arrest when he tells his disciples to arm themselves, and Romans I3. All of these passages have been dealt with at length by various authors and so, with the exception of the temple cleansing which is discussed in section four below, they will not be addressed here. ${ }^{\mathrm{Is}}$ Suffice it to say that Christian anarchists see the logical conclusion of Jesus' teachings on nonviolence to be anarchism - anarcho-pacifism, to be precise.

Anarcho-pacifism, however, is a minority position in the anarchist community. Indeed, it is not uncommon to hear pacifism condemned by anarchists in the strongest terms. Albert Meltzer writes, for example, that while "phoney anarchism contains a large streak of pacifism," such radical nonviolence is ultimately no better than "militant liberalism," insofar as it "renounce[es] any form of positive action for anarchism," and is, therefore,

${ }^{12}$ Bart D. Ehrman, How Jesus Became God: The Exaltation of a Jewish Preacher from Galilee, (New York: HarperOne, 20I4), 225.

13 Ibid., I 28.

${ }^{14}$ Alexandre Christoyannopoulos, Christian Anarchism: A Political Commentary on the Bible, [Abridged Edition], (Exeter: Imprint Academic, 2OII), 44 .

I5 See, for example, Christoyannopoulos, Christian Anarchism. Kevin Daugherty, in "Romans I 3 and the State" (available from http://mennonerds.com/ romans-I3-and-the-state/), argues that Romans I 3 may not be referring to governing authorities at all, but rather to spiritual authorities. 
"authoritarian." ${ }^{16}$ If Meltzer is correct, by no means can we consider Christian nonviolence - or any position of nonviolence, for that matter - to be inherently anarchist. What Meltzer's view fails to appreciate, however, is the fact that it is possible to draw a stronger line between Christian nonviolence, Christian anarchism, and the broader anarchist tradition.

\section{Normativity, Anti-Normativity, and Prefiguration}

The question of ethics is potentially an insurmountable barrier separating Christian and non-Christian anarchists. After all, it seems obvious that the Christian, qua Christian, is expected to follow a very specific set of moral laws, in obedience to the greatest authority of them all, God. Anarchists, on the other hand, have historically spurned normative ethics as necessarily authoritarian. This is not to say that anarchists advocate some form of amorality or moral relativism, but, as Nathan Jun explains in Anarchism and Political Modernity,

In the place of normativity, the anarchists offer two alternatives: first, a sophisticated anthropological, sociological, and evolutionary analysis of the origins and functions of moral systems; and second, a pragmatic and procedural theory of action referred to as 'prefiguration.' ${ }^{17}$

The most obvious example of the first alternative is Peter Kropotkin's work, Mutual Aid, in which he argues that, "Sociability is as much a law of nature as mutual struggle." ${ }^{18}$ Countering the modern-day form of individualism that insists upon a greedy, self-interested human nature, Kropotkin argues,

The very persistence of the clan organization shows how utterly false it is to represent primitive [humankind] as a disorderly agglomeration of individuals, who only obey their individual passions, and take advantage of their personal force and cunningness

${ }^{16}$ Albert Meltzer, Anarchism: Arguments For \& Against ( $6^{\text {th }}$ Second Revised Edition), (San Fransisco: AK Press, I996), 25.

${ }^{17}$ Jun, I29.

I8 Peter Kropotkin, Mutual Aid: A Factor of Evolution, (Mineola: Dover Publications, Inc., 2006), 5. 
against all other representatives of the species. Unbridled individualism is a modern growth, but it is not characteristic of primitive [humankind]. ${ }^{19}$

As to the second alternative that Jun cites, there are many examples in anarchist literature, but perhaps the most pithy statement of anarchist prefiguration is found in Jean Grave's "Means and Ends," in which he writes, "[t]he surest means of making Anarchy triumph is to act like an anarchist." ${ }^{20}$ Jun develops this theme, writing that "The 'prefigurative principle' demands coherence between means and ends. That is, if the goal of political action is the promotion of some value, the means and methods employed in acting must reflect or prefigure the desired end." ${ }^{21}$ In short, means must be consistent with ends. Coercive means cannot be expected to lead to non-coercive ends.

How can such an approach to morality possibly be squared with the approach wherein morality is a function of God's commandments? Rather than "No gods, no masters," it seems that Christian anarchists simply proclaim, "No other gods, no other masters, besides God," which, while it may yield some interesting political implications in its own right, certainly sounds antithetical to anarchism. However, I will argue that both of these alternatives to normativity - the evolutionary and the prefigurative - can in fact find a good deal of support in the teachings of Jesus, particularly when we pay close attention to Jesus' declaration that, "the kingdom of God is among (or within) you." ${ }^{22}$

\section{(a) Mutual Aid and the Unkingdom}

In Mutual Aid, Kropotkin notes that, "Even the new religions which were born from time to time" in the shadow of empires,

i9 Ibid., 7I.

20 Jean Grave, "Means and Ends," in Anarchism: A Documentary History of Libertarian Ideas, Volume One: From Anarchy to Anarchism $(300 \mathrm{CE}$ to I 939), edited by Robert Graham, (Montreal/New York/London: Black Rose Books, 2005), I 57.

2I Jun, I 29.

22 Luke I 7:2 I 
found their first supporters among the humble, in the lowest, down-trodden layers of society, where the mutual-aid principle is the necessary foundation of every-day life; and the new forms of union which were introduced in the earliest Buddhist and Christian communities, in the Moravian brotherhoods and so on, took the character of a return to the best aspects of mutual aid in early tribal life. ${ }^{23}$

It is tempting (and I think rightly so) to read this alongside Jesus' words, "Blessed are you who are poor, for yours is the kingdom of God." ${ }^{24}$ If the kingdom of God is among us, and belongs principally to the poor, it seems that Jesus and Kropotkin may (however unwittingly) be striking a similar chord. For what "kingdom" is found among the lowly and downtrodden of society? As David Graeber notes, we tend to find more empathy, compassion, and solidarity among the working classes - where mutual dependence is among the greatest of life's necessities - than we do among the wealthy, where cooperation is too often cast off in favour of competition and personal gain. ${ }^{25}$

Jesus' kingdom is the one that belongs to the poor, and, in a sense, we might say that Kropotkin's is as well. But this is not, of course, a kingdom in the familiar sense of the word, but something more like what Mark Van Steenwyk calls an Unkingdom. ${ }^{26}$ And if Jesus is the king, we could not but call him an "Unking," for his "rule" (or "unrule," as it were) is one not of violence and conquest, but of love, hospitality, and nonviolent resistance. Accordingly, when Jesus says that, "My kingdom is not of this world," we can read him not as declaring the existence of an otherworldly kingdom, located elsewhere in the universe or beyond, but rather as proclaiming a coming earthly kingdom that looks nothing like the kingdoms of this present world. As W.H. Auden

\footnotetext{
23 Kropotkin, 247.

${ }^{24}$ Luke 6:20

25 David Graeber, “Caring Too Much. That's the Curse of the Working Classes," available from http://www.theguardian.com/commentisfree/20I4/mar/26/ caring-curse-working-class-austerity-solidarity-scourge? $\mathrm{CMP}=\mathrm{fb} \_\mathrm{gu}$. (accessed 3I July 20I 5 ).

${ }^{26}$ Mark Van Steenwyk, The UNkingdom of God: Embracing the Subversive Power of Repentance, (Downers Grove: InterVarsity Press, 2013).
} 
writes, "Jesus said My Kingdom is not of this world. He did not say of the world." ${ }^{27}$

Thus, we find - perhaps surprisingly, given Kropotkin's hostility to religion - a connection between the teachings of Jesus and Kropotkin. Jesus preaches a kingdom of love and compassion and declares not only that it is among us but also that it belongs to the poor. Kropotkin draws upon evolutionary science to argue that human beings are cooperative by nature, and that this principle of mutual aid is found particularly well preserved among the poor, who are, not surprisingly, those praised by Jesus for their proximity to the kind of politics he seeks to illustrate. We certainly should not conflate the teachings of Jesus with Kropotkin's writings, considering the obvious and dramatic differences between the two. All I mean to draw out here is the specific compatibility between Jesus' Unkingdom and Kropotkin's writings on mutual aid and show how a Christian and non-Christian anarchist can find common ground.

By this account, then, we have good reason to say that the Unkingdom of God and the principle of mutual aid are naturally compatible: mutual aid is typically found among the downtrodden (to whom Jesus points), and is indeed an essential characteristic of an anarchist society such as Jesus' Unkingdom. Therefore, the "sophisticated anthropological, sociological, and evolutionary analysis of the origins and functions of moral systems" which anarchists prefer to a religious ontology in fact meets the political recommendations that follow from that ontology on the question of ethics.

Of course, there are some anarchists - probably individualists in the fashion of Max Stirner in particular - who may take issue with Kropotkin's argument and thus will not be interested in the question of whether or not it is compatible with the Unkingdom. The question then becomes: should we accept that Kropotkin's basic view of ethics - as a result of our evolutionary development as social creatures - is a necessary component to any and all anarchist accounts of ethics? This is of course a thorny issue because

${ }_{27}$ W.H. Auden, quoted in Richard Kearney, Anatheism: Returning to God After God, (New York: Columbia University Press, 20I I), I35. 
any talk of "the" anarchist view on something - anything - is by its very nature extremely difficult. Accordingly, I would respond to anti-Kropotkin objectors with two main points: first, I would agree with Jun that this approach to ethics can reasonably be considered a basic component of historical anarchist approaches to ethics; and second, as work in contemporary evolutionary biology frequently shows, there are good grounds for taking Kropotkin's arguments seriously. ${ }^{28}$ Accordingly, while I would certainly concede that it is difficult if not impossible to assert any view as "the" anarchist position, I would argue that anarchists have very good reason to accept Kropotkin's argument both as historically important for anarchism as well as important for such contemporary debates as to whether or not human beings can live peaceably without hierarchy or centralized government.

\section{(b) Prefiguring the Unkingdom}

Jesus paradoxically preaches a kingdom already-come and an apocalyptic kingdom to-come. And herein, I want to argue, lies Jesus' prefigurative principle. Jesus calls his followers to make this coming kingdom ever more real through concrete acts of love and hospitality. Lee Camp refers to this as living "proleptically": "If the Kingdom of God has broken in . . . then the church is to live proleptically according to the now-present-and-coming Kingdom. To live proleptically means to live now according to something that is still yet in the future[.]" 29

We find the clearest expression of how we are to live proleptically in the Sermon on the Mount, wherein we find Jesus' most explicit teachings of radical love, forgiveness, and nonviolence: "Do not resist an evildoer," ${ }^{\circ}$ "Give to everyone who begs from you," ${ }_{31}$ "Love your enemies and pray for those who persecute

\footnotetext{
${ }_{28}$ See, for example, Frans de Waal, The Age of Empathy.

29 Lee C. Camp, “What About Romans I3: 'Let Every Soul Be Subject'?”, in A Faith Not Worth Fighting For: Addressing Commonly Asked Questions About Christian Nonviolence, edited by Tripp York and Justin Bronson Barringer, (Eugene: Cascade Books, 2012), I42.

30 Matthew 5:39.

${ }^{31}$ Matthew 5:42.
} 
you," ${ }_{22}$ "do not worry about your life, what you will eat or what you will drink." ${ }_{33}$

But surely, we object, we must defend ourselves against aggressors? Surely we cannot be expected to give to everyone who begs from us? Surely we cannot love terrorists? Surely we have to plan for retirement?

Maddeningly, however, Jesus offers no exception clauses. Indeed, Leo Tolstoy insists that when Jesus taught nonviolence, he "meant neither more nor less than what he said." ${ }_{34}$ D. Stephen Long similarly writes,

Nowhere does Jesus' Sermon on the Mount suggest that it is only for individuals. There is no footnote or proviso where Jesus says, 'You are to live this way except when it comes to the defence of your neighbours, then you must use the violence at your disposal to protect them.' In fact, the Sermon on the Mount is not private instruction for individual consciences; it is the political platform for the new kingdom or city that Jesus proclaims, the city that is to be 'set on a hill' and illumine the world (Matt 5:I4-I6).35

Gustav Landauer, as anarchists are fond of repeating, argues that "The state is a relationship between human beings, a way by which people relate to one another; and one destroys it by entering into other relationships; by behaving differently to one another." ${ }^{36}$ With this in mind, the Sermon on the Mount is a call to radically rethink and reorient our relationships with one another in a way that prefigures the Unkingdom of God. It may seem impossible, but, as Jesus says, "for God all things are possible." ${ }_{7}$

${ }^{32}$ Matthew 5:44.

33 Matthew 6:25.

34 Leo Tolstoy, What I Believe, translated by Huntington Smith, (Guildford: White Crow Books, 2009), I 6.

35 D. Stephen Long, "What About the Protection of Third-Party Innocents? On Letting Your Neighbors Die," in York and Barringer, 2 I.

${ }^{36}$ Gustav Landauer, "Destroying the State By Creating Socialism," in Anarchism: A Documentary History of Libertarian Ideas, Volume One: From Anarchy to Anarchism (30oCE to I 939), edited by Robert Graham, (Montreal/New York/London: Black Rose Books: 2005), I 65.

37 Mark I0:27 
What does this Unkingdom look like? Or to ask in John Caputo's provocative words,

What would it be like were there a politics of and for the children, who are the future; a politics not of sovereignty, of topdown power, but a politics that builds from the bottom up, where ta me onta (I Cor I:28) enjoy pride of place and a special privilege? What would a political order look like if the last are first, if everything turned on lifting up the lowliest instead of letting relief trickle down from the top? What would it look like if there were a politics of loving one's enemies, not of war, let alone, God forbid, of preemptive war? ${ }^{38}$

In short, I would follow the many Christian anarchists who have argued ${ }^{39}$ that it would look like anarchy. $4^{\circ}$ And Jesus does not say that his teachings in the Sermon on the Mount are simply meant to indicate how we will live once the Unkingdom has arrived, some distant day in the future, for the Unkingdom has arrived. ${ }^{\mathrm{I}}$ It is already amongst us in the communality of the poor and lowly, and it is realized in every concrete act of love, hospitality, and forgiveness. Accordingly, there are no exception clauses or provisos. Jesus is teaching a new way of being for the here and now - a new way of being that prefigures the already-here-yetstill-to-come Unkingdom. We are to care for the poor today, to welcome strangers and love our enemies today, and to put away our swords today. For, as Richard Kearney says,

The kingdom is present in the '[1]east of these,' just as Christ is present in the giving of a cup of cold water. That means that in every moment, there is the possibility of good and the possibility of nongood. There's the possibility of love; there's the possibility of hate, violence, aggression. We're choosing constantly. And every moment we are actualizing the kingdom or not-actualizing the kingdom. ${ }^{42}$

${ }^{8}$ John D. Caputo, What Would Jesus Deconstruct? The Good News of Postmodernity for the Church, (Grand Rapids: Baker Academic, 2007), 87.

39 See Christoyannopoulos, Christian Anarchism.

$4 \circ$ Caputo in fact refers to this as "sacred anarchy," but by this he does not have anything like political anarchism in mind.

${ }^{4}$ That is, it has arrived as per our blending of Jesus and Kropotkin above.

${ }^{42}$ Richard Kearney, "Theorizing the Gift," in Debates in Continental Philosophy: Conversations with Contemporary Thinkers, edited by 
Caputo similarly says that the kingdom of God "is feeding the hungry. . visiting the imprisoned, curing the sick. That is the kingdom of God." 43

Otherwise, if we are to play no role in the establishment of the kingdom, but are rather expected simply to sit and wait for God to come down and do it all for us, I think we render both ourselves and Christ impotent. For we can neither do anything on our own and neither will following the way of Christ do us any good either. Both our actions and Christ's teachings are essentially useless. We fall into this trap by thinking that we face an either/or: either we establish the kingdom, or God does. But this has dangerous implications. For one thing, such a move seems to result in an absolute, unbridgeable chasm between God's transcendence and our immanence. In other words, we end up with an essentially Gnostic separation between the utterly depraved, corrupt, and fallen world, on the one hand, and the absolutely perfect, unblemished spiritual world on the other. Clayton Crockett warns us of the danger here:

Any time one posits two planes, a plane of transcendence and a plane of immanence, the problem becomes the mediation, in both ontological and metaphysical terms, between the two planes. If God is simply located on a transcendent plane, then knowledge of God is impossible and religion is reduced to the problem of political obedience. ${ }^{44}$

The alternative is to follow Caputo and Kearney in saying that we in fact participate with God in the realization of the kingdom, and that Christ did in fact intend for his teachings to be followed. As Kearney says, "We actualize what God possibilizes and God possibilizes what remains impossible for us." 45 According to this view, God could not establish the kingdom without us, for there would be no one to give flesh to the kingdom through following

Richard Kearney, (New York: Fordham University Press, 2004), 29 I.

43 John Caputo, "On the Event in Christianity," available from https://youtu.be/R2nq8baHDFY (accessed 29 November 201 5 ).

${ }_{44}$ Clayton Crockett, Radical Political Theology, (New York: Columbia University Press, 20II), 68.

45 Kearney, 293. 
Christ's teachings and example - "God can't create the kingdom unless we create the space for the kingdom to come," as Kearney says $^{46}$ - just as we could not establish the kingdom without God, for then the impossible would remain impossible.

The greatest biblical examples of this are to be found in the parable of the sheep and the goats ${ }^{47}$ and Jesus' appearing as a stranger on the road to Emmaus..$^{8}$ The argument of both of these passages is that when we welcome the stranger we welcome Christ, and when we deny the stranger we deny Christ, which is to say that Christ does not appear if we do not act. Kearney draws a connection here between Matthew 25 and Jesus' famous words that "no one comes to the Father but through me" 49 in the following way: "You can only come to the Father if you come through me. Who am I? I am every stranger who asks for food and water." ${ }^{\circ}$ Christ is in the face of the stranger, which means that his kingdom - his Unkingdom - is built by welcoming the stranger.

This does not mean that Christ is ours to control, however, for when we welcome Christ we welcome the one who possibilizes what is for us impossible. Once again, it is not a strict either/or. As Kearney says elsewhere, “I don't believe there's an absolute God out there and then a completely compromised humanity here. I think there are constant to-ings and fro-ings." ${ }^{\text {I }}$ Besides love and hospitality, my argument in this paper is that nonviolence is another way that we spurn the worldly logic of tit-for-tat violence and create a space in which Christ's impossible Unkingdom can be realized, opening a door for these "to-ings and fro-ings."

But how can we say, as was done above, that "for God all things are possible"? How does this not negate all that has been said thus far and land us back at square one, with the case for Christian nonviolence ultimately resting upon calls

\footnotetext{
${ }^{46}$ Ibid., 286.

7 Matt. 25:3 I-46.

${ }^{8}$ Luke 24:I3-43.

49 John I $4: 6$.

50 Richard Kearney, “Anatheism,” interview by Josef Gustafsson and David Capener, Freestyle Christianity, I7 February 2016, available from: http:// www.freestylechristianity.se/podcast/richard-kearney-anatheism/ (accessed 3I May 20I6).

${ }^{5}$ Kearney, “Theorizing the Gift," 287.
} 
to obey an authoritarian God? Are we not abdicating human responsibility?

According to I John, "God is love." ${ }_{52}$ Based upon this simple yet profound claim, Ellul writes, "the true face of the biblical God is love. And I do not believe that anarchists would be too happy with a formula that runs: No love, no master." ${ }_{53}$ Furthermore, as Caputo reminds us, "love is a how, not a what," ${ }^{44}$ meaning God, too, "is a how, not a what." ${ }_{55}$ This may be a provocative and controversial statement, but it helpfully reminds us that God is not necessarily an extrinsic deity, a distant ruler 'out there.' The Kingdom of God - the Unkingdom ruled by Jesus Christ - is principally a Kingdom of love. And love does not hand down laws with an iron fist or mete out punishment to those who disobey. "There is no fear in love," writes the author of I John, "but perfect love casts out fear; for fear has to do with punishment, and whoever fears has not reached perfection in love." ${ }_{56}^{6}$ Nor, however, does love allow us to stand idly by and allow injustice to go unchallenged.

Much like Caputo's notion of God as a weak force, which lays an absolute claim upon us, but does so without an army to enforce its claim; ${ }^{57}$ or Kearney's God-Who-May-Be, who cannot be unless we act in the world to bring God about in concrete moments of love and hospitality, ${ }^{58}$ love commands with more power than any force in the world, and yet is utterly powerless to act on its own, without our choosing it. It will not allow passivity any more than force. This weak force, or may-be, is Christ's broken body on the cross, contrasted with the authoritarian state. "[T]he

52 I John 4:I6b.

53 Jacques Ellul, Anarchy and Christianity, translated by Geoffrey W. Bromiley, (Eugene: Wipf \& Stock, 20II), 35.

${ }_{54}$ John D. Caputo, On Religion, (London \& New York: Routledge, 200I), I34.

55 Ibid., I35.

${ }^{56}$ I John 4: I8.

57 John D. Caputo, "Spectral Hermeneutics," in After the Death of God, edited by Jeffrey W. Robbins, (New York: Columbia University Press, 2007).

$5^{8}$ Richard Kearney, The God Who May Be, (Bloomington \& Indianapolis: Indiana University Press, 200I). 
ways of the world are the ways of power," ${ }_{99}$ says Caputo. And Christ's weakness on the cross is the absolute reversal of this power. It is not merely that Christ hides or restrains his power on the cross; rather, as Caputo insists, it is precisely in Christ's genuinely helpless state that we find the sacredness of the crucifixion:

The sacredness lies in the cries of protest that rise up from the scene. The event to be willed here is the depth of outrage at the injustice of imperial power, of the crushing of the Kingdom by worldly forces. The divinity lies in the identification of the name of God, for Jesus was the eikon of God, not with Roman power but with an innocent victim of that power, not with retribution but with the act of forgiveness that is attributed to Jesus by the evangelists. ${ }^{60}$

The name of God, then, is not the name of a supreme, all-powerful alpha-Being, but rather of "a restive possibility that makes the world restless with hope for justice and impatient with injustice, while the actuality or the realization is assigned to us[.]" ${ }^{6 \mathrm{I}}$ To say that God is love is to say that God does not deal in the worldly ways of power and force, but rather that God disturbs these all-too-human ways of being and calls for something new - challenging $u s$ to be the ones to actualize this something new. This is a radically covenantal understanding of God. Indeed, Kearney argues that a more faithful translation of the Hebrew 'ebyeh asher 'ehyeh - God's words to Moses in Exodus 3:I4, typically translated as "I am who I am" is "I am who may be." ${ }^{62}$ Accordingly, Kearney argues that God should be read here as promising to be, on the condition that we uphold our end of the bargain: "Be what? . . . Be what is promised as it is promised. And what is that? . . A kingdom of justice and love." 63

Like Caputo, Kearney insists that the most important word when speaking of God is perhaps. And perhaps does not mean

\footnotetext{
59 Caputo, "Spectral Hermeneutics," 63.

60 Ibid.

6r Ibid., 64 .

${ }^{62}$ Kearney, The God Who May Be, 22.

63 Kearney, 38.
} 
that God is impotent, but it does mean that God is weak as opposed to the all-too-human obsession with power and sovereignty that seems to dominate the current political and theological arenas. There is nothing divine about demanding constant, absolute control - a demand which is the truer mark of fear and insecurity, it seems. Divinity, rather, is to be found in the faces of power's victims, of the lowly and downtrodden, who do not allow us to turn a blind eye to injustice. "Truly I tell you," Jesus says in Matthew 25, "just as you did it to one of the least of these who are members of my family, you did it to me." ${ }^{4}$

If, then, instead of saying that God commands, what Christians say is actually that love commands, then non-Christian anarchists might find it easier to agree, and this does not conflict with anarchist commitments to antiauthoritarianism. For, as Errico Malatesta writes, "ours is a struggle inspired by love." ${ }_{55}$ Most Christians will obviously not want to say that this is all that it means, nor will atheist anarchists want to say that love is "the true face of the biblical God." My suggestion is simply that both could find common ground with this notion of God as love. Christian anarchists, then, could somewhat daringly describe prefiguration of an anarchist community of mutual aid as the very embodiment of God - indeed of the Body of Christ. ${ }^{66}$

${ }^{64}$ Matt. 25.

${ }^{65}$ Errico Malatesta, "Violence as a Social Factor," in Anarchism: A Documentary History of Libertarian Ideas, Volume One: From Anarchy to Anarchism (30oCE to I939), edited by Robert Graham, (Montreal/ New York/London: Black Rose Books: 2005), I63.

${ }^{66}$ It is interesting to note, as an aside, the similarity between this position and that of death of God theologians, who argue in Hegelian fashion that the dialectic of God the Father and God the Son has, following the crucifixion of Christ (in whom God's entire being had been emptied via radical kenosis), found its resolution in the Holy Spirit. The Holy Spirit, according to this view, manifests itself in the church, such that the church is, quite literally, the body of Christ immanent in the world. (For a helpful, more in-depth discussion of this view, see Homebrewed Christianity's interview with Christopher Rodkey here: http://homebrewedchristianity. com/20I 5/07/I 8/when-a-radical-theologian-gets-in-the-pulpit/) 


\section{Enemy-Love}

But can this love be reasonably expected to extend to our enemies - viz., our oppressors - as Jesus teaches? I would argue that all that has been said thus far leads most naturally to radical, Christ-like enemy-love. For the love that Jesus teaches the love that prefigures the Unkingdom - is indiscriminate. As Søren Kierkegaard argues in Works of Love,

Your neighbor is every man [sic], for on the basis of distinctions he is not your neighbor, nor on the basis of likeness to you as being different from other men. He is your neighbor on the basis of equality with you before God: but this equality absolutely every man has, and he has it absolutely. ${ }^{67}$

And, consequently, "by being a Christian he does not become free from distinctions, but by winning the victory over the temptation of distinctions he becomes a Christian." ${ }^{68}$ It is therefore impossible, from a Christian perspective, to distinguish between those who deserve our love and those who do not. Human life must be taken to be inviolable, and there can therefore be no hierarchising of who is more or less valuable and therefore deserving of love, forgiveness, and hospitality. There can be no adjudicating between one's "goodness" and "badness." Again, Jesus offers no exception clauses. If we are to value any one human life indiscriminately, we must value them all the same. To do otherwise would be to deny the inherent value, dignity, and equality of every human person, and to admit that human value can be earned and forfeited. Walter Wink is particularly helpful on this point:

Commitment to justice, liberation, or the overthrow of oppression is not enough, for all too often the means used have brought in their wake new injustices and oppressions. Love of enemies is the recognition that the enemy, too, is a child of God [or Love]. The enemy too believes he or she is in the right, and fears us because we represent a threat against his or her values, lifestyle, or affluence. When we demonize our enemies, calling them names and

\footnotetext{
${ }^{67}$ Søren Kierkegaard, Works of Love, translated by Howard and Edna Hong. (New York: Harper Perennial, 2009), 72.

68 Ibid., 8 I.
} 
identifying them with absolute evil, we deny that they have that of God within them that makes transformation possible. Instead, we play God. ${ }^{69}$

Wink reminds his readers that even one's worst enemy is a person too. First and foremost, therefore, we should seek reconciliation, rather than further alienation and fragmentation of our already damaged relationships with one another. In fact, if reconciliation is not achieved, the conflict will likely be perpetuated indefinitely, continuing the cycle of violence, until one side manages probably through sheer brute force - to dominate the other into submission. Wink continues:

Unless these people are exterminated in a genocidal war or an endless guerrilla insurrection, they must be converted. And no one can show others the error that is within them . . unless the others are convinced that their critic first sees and loves the good that is within them. ${ }^{70}$

\section{Two Types of Objections}

There are two obvious standpoints from which objections to my argument can be raised. First, objections may be levelled against my biblical argument for nonviolence - viz., it may be objected that the Bible (specifically Jesus' teachings as found in the Gospels) does not in fact lend itself to my radical nonviolence thesis. Second, it may be objected that nonviolence does not in fact work. I will attempt to address each of these in turn.

\section{(a) Biblical Objections}

There are three main New Testament passages that are cited in objection to biblically based arguments for nonviolence: Jesus' cleansing of the temple, Jesus' telling his disciples to arm themselves, and Paul's admonition to obey the governing authorities

69 Walter Wink, Jesus and Nonviolence: A Third Way, (Minneapolis: Fortress Press, 2003), 59.

70 Ibid., 62. 
in Romans I3. As stated above, the latter two in particular (as well as the "render unto Caesar" passage) have been skilfully addressed many times over by Christian anarchists and pacifists and so will not be considered here. I will, however, consider the temple cleansing as doing so serves a dual purpose - namely, it allows the response to the biblical objection as well as addresses the larger question of civil disobedience and property destruction.

According to the Gospel of John, "In the temple [Jesus] found people selling cattle, sheep, and doves, and the money changers seated at their tables. Making a whip of cords, he drove all of them out of the temple, both the sheep and the cattle." ${ }^{71} \mathrm{At}$ first blush, this passage appears to show Jesus acting violently. However, Christian anarchists and pacifists have convincingly argued that this passage is in fact consistent with the view of Jesus as a nonviolent revolutionary.

All four Gospel writers recount Jesus' cleansing of the temple, but it is only in John that we are told of a whip. This may have something to do with the fact that, as John Dear writes, "Most scholars agree that John deliberately paints Jesus as a righteous prophet in the tradition of Jeremiah, who engaged in similar dramatic actions." ${ }^{2}$ John would therefore have a greater interest in emphasising just how filled with righteous anger Jesus was. But did Jesus' anger lead him to strike people and animals with his makeshift whip? Christian pacifists argue that such an interpretation would be erroneous.

John Dear insists that Jesus' becoming violent in this episode "would be entirely inconsistent with the Jesus portrayed throughout John's Gospel, as well as the Synoptics." 73 We should therefore be wary from the outset of any translation that depicts a violent Jesus. Indeed, Andy Alexis-Baker skilfully argues that a careful study of the Greek demonstrates that the most faithful translation is the one cited above: "he drove all of them out of the temple, both the sheep and the cattle" (emphasis added). In other words,

\footnotetext{
${ }^{71}$ John 2:I4-I 5

${ }^{72}$ John Dear, "Didn't Jesus Overturn Tables and Chase People Out of the Temple with a Whip?" in York and Barringer, s 88.

73 Ibid., I 89.
} 
at most Jesus' whip is used against the animals but never against any people.

But the suggestion that Jesus would whip the animals is similarly troubling for Christian pacifists. However, as Alexis-Baker goes on to argue,

We might go further and deny that Jesus committed 'violence' against the sheep and cattle, since a makeshift whip of rope would hardly do much more than get them moving out the door. . in a real sense, the narrative does not depict Jesus beating the animals; but instead he saves their lives from sacrificial slaughter in a monetary and religious system. ${ }^{74}$

In other words, Jesus was liberating both humans and animals from the economic system of slaughter. His overturning of the moneychangers' tables is symbolical of his overturning the calculating kingdoms of the world and inaugurating a new Unkingdom marked by the free gifts of love, grace, and forgiveness.

We are left with the reality of property destruction in this passage, but this should not be seen as problematic. It is not uncommon in the $2 \mathrm{I}^{\text {st }}$-century to hear property destruction lumped under the category of 'violence' alongside violence committed against persons. Such a disturbing trend seems to suggest that broken windows and broken bones are essentially the result of the same offenses - viz., 'violence.' Uri Gordon's Anarchy Alive! provides a helpful discussion of the way in which this reclassification of property destruction as 'violence' is essentially a divide-andconquer strategy. If the actions of activists can be divided between categories such as legal and illegal, legitimate and illegitimate, non-violent and violent - where 'violent' may mean nothing more than a broken window - citizens and activists can be effectively divided against one another and, consequently, more easily controlled and pacified.

The crucial question to ask is, why is a brick thrown through a window 'violent' and the police officers' use of tear gas, water cannon, etc. on the brick-throwers not? Such a division of violent and nonviolent along the lines of illegal and legal is highly

74 Andy Alexis-Baker, Violence, Nonviolence and the Temple Incident in John 2:I3-I 5," in Biblical Interpretation 20 (20I2), 94. 
suspect. Gordon suggests that the motivation here is "strongly connected to a fear of the uncontrollable, the abnormal and the criminal," 75 and that order-preserving violence therefore comes to be seen as justified, legal, and, ultimately, nonviolent, whereas action that threatens the social order is classified as unjustified, illegal, and violent (these words becoming synonymous at this point). Social movements consequently become much more easily fractured, weakened, and delegitimized, insofar as they are carved up into 'legitimate' and 'illegitimate' camps, often contributing to internal discord as well as turning the public against the 'violent' and 'illegitimate' groups.

We should therefore see the classification of property destruction as another form of 'violence' as nothing more than an attempt to further demonize civil disobedience and protect the established order. Indeed, if we follow the common anarchist argument that the law exists primarily - if not exclusively - to protect private property (and private property, as Proudhon teaches, is theft), then the property-destruction-is-violence move clearly favours plutocracy over democracy.

In a passage often used to denounce Christian nonviolence and condone the state's violent protection of property, then, we in fact find yet another instance of Jesus' radical, nonviolent subversion of the established order. The temple cleansing serves as a reminder that, in Dear's words, "the nonviolent Jesus was decidedly not passive." ${ }^{6}$ And neither should we be. Jesus shows why pacifism and nonviolence should not be confused with passivism and non-resistance.

\section{(b) Practical Objections}

Perhaps the most common objection levelled by both Christians and non-Christians, anarchists and non-anarchists, is that nonviolence simply does not work. Ward Churchill, for example, condemns the common methods of nonviolent protest, in which "[o]ne will find hundreds, sometimes thousands, assembled in

75 Uri Gordon, Anarchy Alive! Anti-Authoritarian Politics from Practice to Theory, (London \& Ann Arbor: Pluto Press, 2008), 83.

${ }^{76}$ Dear, 185 . 
orderly fashion, listening to selected speakers calling for an end to this or that aspect of lethal state activity, carrying signs 'demanding' the same thing," 77 and it is indeed hard to deny that these are generally unsuccessful in effecting immediate and meaningful structural change.

However, perhaps the solidarity that is cultivated and the teaching and raising of public awareness can allow even these seemingly useless protests to have an impact. It does not mean that other tactics will not be open to and even necessary for loving nonviolence (or what Keith Hebden helpfully refers to as "compassionate activism" $\left.{ }^{8}\right)$. Nonviolence can take many forms, such as teaching, writing, feeding the homeless, and starting community gardens, all of which challenge state violence and coercion through building a new world in the shell of the old. And sometimes it might be necessary to flip some tables over, so to speak - i.e., to engage in nonviolent direct action which denounces the state's abuse of political, economic, military, and religious power. This is, after all, wholly consistent with Jesus' life and teachings.

More specifically, one of the most important ways that Christian anarchists respond to this type of objection is by arguing that nonviolence is the only way to escape the cycle of violence. Quite simply, it is argued, responding to violence with further violence only increases the amount of violence in the situation, and the cycle of tit-for-tat violence will continue indefinitely. Equating violence with slavery, Tolstoy writes, "all attempts to abolish slavery by violence are like extinguishing fire with fire, stopping water with water, or filling up one hole by digging another." 79 This basic argument is repeated again and again in the Christian anarchist literature. ${ }^{\circ \circ}$ Jacques Ellul, for example, lists this as one of

77 Ward Churchill, Pacifism As Pathology, (Oakland: AK Press, 2007), 6I-62.

${ }^{78}$ Keith Hebden, Seeking Justice: The Radical Compassion of Jesus, (Washington: Circle Books, 2013), I6.

79 Leo Tolstoy, "The Slavery of Our Times," in Government is Violence: Essays on Anarchism and Pacifism, edited by David Stephens, (London: Phoenix Press, I990), I45.

8० See Christoyannopoulos, Christian Anarchism, for a helpful and thorough overview. 
his laws of violence: "Violence begets violence - nothing else." Furthermore, Ellul writes, "once we consent to use violence ourselves, we have to consent to our adversary's using it, too." ${ }^{82}$ In other words, not only do we enter the cycle of violence when responding violently, we in fact affirm this cycle insofar as we affirm that violence is an effective means to our desired end.

Accordingly, when Peter Gelderloos condemns nonviolence as racist, statist, patriarchal, and otherwise in line with the status quo, ${ }^{83}$ Christian anarchists can respond that, insofar as violence is the primary way in which this racist, statist, patriarchal status quo is enforced, nonviolence is in fact a powerful challenge to the status quo - a means of not being conformed to the ways of the world.

Furthermore, nonviolence can arguably unmask state violence more effectively than violence can, as when, for example, we see sit-down protestors being attacked by police ${ }^{84}$ or nonviolent Palestinian protestors gunned down by Israeli forces. Recent headlines - such as Sharif Abdel Kouddous' article for The Nation entitled "Palestinians Engaged in Nonviolent Protest. Israel Responded With a Massacre," ${ }_{55}$ or The Real News Network's interview with Michael Omer-Mann entitled "IDF Prepares to Kill More Peaceful Protesters in Gaza on Friday" ${ }^{86}$ - appear to appeal

${ }^{8}$ I Jacques Ellul, Violence: Reflections From A Christian Perspective, translated by Cecilia Gaul Kings, (Eugene: Wipf \& Stock, 20I I), Io०.

82 Ibid., 99.

${ }_{3}$ See Peter Gelderloos, How Nonviolence Protects the State, available from http://theanarchistlibrary.org/library/peter-gelderloos-how-nonviolenceprotects-the-state

${ }^{84}$ James Crugnale, "UC Davis Police Pepper Spray Student Occupy Protestors, University Investigating Incident," Mediaite, I9 November 20 I I. Available from http://www.mediaite.com/online/uc-davis-police-pepper-spray-studentoccupy-protestors-university-investigating-incident/. Accessed 3 I July 20 I 5 .

${ }_{5}$ Kouddous, Sharif Abdel. "Palestinians Engaged in Nonviolent Protest. Israel Responded With a Massacre," The Nation, I7 May 2018. Available from https://www.thenation.com/article/palestinians-engaged-in-nonviolentprotest-israel-responded-with-a-massacre/ (accessed I7 May 20I8).

${ }^{86}$ The Real News Network, "IDF Prepares to Kill More Peaceful Protesters in Gaza on Friday,” I7 May 2018. Available from https://therealnews. $\mathrm{com} /$ stories/idf-prepares-to-kill-more-peaceful-protesters-in-gaza-onfriday (accessed I7 May 20I8). 
precisely to the sense of injustice that can be aroused within readers in the face of such violent responses to nonviolent protestors. To be sure, it would be an unhelpful oversimplification to say, definitively, that violent protest never has and never could have similar impacts on public awareness, or that nonviolence always has and always will. But I argue that when the protestors are nonviolent, the violence of the state is brought into uniquely sharp relief and is therefore more easily identified as excessive not only by those who already sympathize with the protesters' cause, but also by those who might otherwise accept the legitimacy of state violence. For, in such instances, the state's violence stands fully exposed, unable to dull itself against images of aggression on the part of the protesters or to hide behind justifications of 'self-defence' or 'keeping the peace.'

Thus, contrary to someone such as Chu Minyi, who goes so far as to argue that "assassination will help arouse revolutionary agitation and quicken social revolution," ${ }_{77} \mathrm{I}$ argue that it is rather these instances of nonviolent resistance that are most likely to awaken the public to injustice. Violent acts such as physical attacks or assassinations, on the other hand, often serve only to confuse the moral sensibilities of a public for whom the state's violence is so normalized that it hardly appears as violent at all and, indeed, it will appear to be only that much more justified when wielded as a form of defence against violent dissent.

Therefore, while we should heed Gordon's warning to avoid playing into the divide-and-conquer strategy of carving up radical groups into 'violent/illegitimate' and 'nonviolent/legitimate' camps, nonviolence in these situations has the pragmatic advantage of, first, not alienating the public, and second, allowing the state's violence to stand alone and therefore be unmasked as unnecessary and illegitimate. Christian anarchists and pacifists have long argued that the story of Jesus' crucifixion accomplishes precisely this, insofar as it is the story of a state's crushing nonviolent dissent, and Jesus' persistent nonviolence, love, and forgiveness

${ }_{87}$ Chu Minyi, "Universal Revolution," in Anarchism: A Documentary History of Libertarian Ideas, Volume One: From Anarchy to Anarchism (30oCE to I939), edited by Robert Graham, (Montreal/New York/ London: Black Rose Books: 2005), 345 . 
exposes the Roman government's use of force as excessive and brutal. Read from this perspective, then, the church's historical support for, and participation in, state violence is a betrayal of Jesus' message. ${ }^{88}$

Importantly, the pragmatic appeal to nonviolence should be distinguished from consequentialism. As Benjamin Franks argues, a rejection of consequentialism is one of the key points of differentiation between anarchist direct action and other, non-anarchist forms of civil disobedience:

[D]irect action is prefigurative, the means have to be in accordance with the ends. Civil disobedience is not prefigurative, and it is frequently consequentialist. . .It is this rejection of consequentialism that particularly marks direct action out as especially anarchic. ${ }^{89}$

Prefiguration allows us to take seriously the consequences of our actions while also recognising that those consequences - the ends are inextricably linked to the means. It strikes me as all too easy for consequentialism - at least as it is articulated by those like Minyi - to slip into justifying the sacrificing of a few for the many in the name of a greater end, and thereby instrumentalising human life in a way similar to the instrumentalization wrought by states and capitalism.

The radical and uncompromising affirmation of the inherent value, dignity, and equality of every human person is one of the most subversive and anarchic revolutionary acts. Jesus understood this. It is upon this very affirmation that the Unkingdom that he preached turns. The Unkingdom is embodied in such affirmation and it is the way that we are not conformed to the ways of this world but rather live according to the present-and-coming Unkingdom. Only prefigurative nonviolence, in other words, which privileges neither means nor ends, but rather recognizes the necessary agreement between the two, can allow us to wholly

${ }^{88}$ See Christoyannopoulos, Christian Anarchism.

89 Benjamin Franks, "The Direct Action Ethic," in Anarchism: A Documentary History of Libertarian Ideas, Volume Three: The New Anarchism (I9742OI2), edited by Robert Graham, (Montreal/New York/London: Black Rose Books: 2005), 86. 
escape the cycle of violence that results from, and perpetuates, the instrumentalising, tit-for-tat logic of state and capitalism.

We may also hope that the illegitimacy of state violence effected by this unmasking will be made apparent not only to the protestors and others watching, but even to the aggressors themselves. Indeed, Richard Gregg argues that in this sense nonviolence is "a sort of moral ju-jitsu." $9^{\circ}$ The attacker, according to Gregg,

suddenly and unexpectedly loses the moral support which the usual violent resistance of most victims would render him. . .He feels insecure because of the novelty of the situation and his ignorance of how to handle it. He loses his poise and self-confidence. ${ }^{91}$

The aggressor can no longer refer to their victim, or the situation more generally, as violent; it becomes clear that only the aggressor is acting violently. Such a realization is disorienting and destabilizes the aggressor's moral security.

It may be objected, however, that such an argument depends upon the assumption of some basic level of moral decency on the part of the attacker. However, as Wink argues, "Had Jesus waited for the Romans to achieve a minimum moral level, he never would have been able to articulate the message of nonviolence to begin with. On the contrary, his teaching does not presuppose a threshold of decency, but something of God in everyone." ${ }_{92}^{2}$ Recalling our discussion above of hearing 'love' when we speak of 'God,' Wink's argument is quite powerful:

There is no one, and surely no entire people, in whom the image of God has been entirely extinguished. Faith in God means believing that anyone can be transformed, regardless of the past. To write off whole groups of people as intrinsically racist and violent is to

90 Richard Gregg, quoted in Nicolas Walter, "Direct Action and the New Pacifism," in in Anarchism: A Documentary History of Libertarian Ideas, Volume Two: The Emergence of the New Anarchism (I939-I977), edited by Robert Graham, (Montreal/New York/London: Black Rose Books: 2009), 200.

${ }^{1}$ Ibid.

${ }_{92}$ Wink, 67. 
accept the very same premise that upholds racist and oppressive regimes. ${ }^{93}$

It may certainly be true that institutions can be, and often are, inherently racist and oppressive, but Wink cautions us against forgetting that the people who act on behalf of these institutions are still people. Oppressive institutions such as the state are in the business of taking the easy ways out of imprisonment and execution in response to dissent, condemning rather than engaging persons and groups of persons in their entirety. It should be the business of Christians and anarchists to instead choose the more difficult paths of forgiveness and reconciliation, which demand that we recognize the humanity of even our worst enemies.

Perhaps a more powerful criticism of nonviolence, however, is that spontaneous violence provides a means for repressed bodies especially black, brown, female, non-binary, and queer bodies - to wrench themselves free from the state's grasp and deny the state the ability to control them. This line of argument is hinted at, for example, in "Reflections on the Ferguson Uprising," when one of the anarchists being interviewed says, "having those moments of uncontrollability or possibility open up. . .will entail violence." ${ }^{44}$ This is a very important argument given the fact that, in the wake of the Ferguson and Baltimore uprisings, it is increasingly common to hear the action of a black man who throws a brick through a window be condemned as that of a violent 'thug.' ${ }^{5}$ Calls to emulate Martin Luther King Jr. subsequently ring out as not-so-subtle attempts to rein disobedient bodies back into the establishment's control. As Ta-Nehisi Coates points out in an article for The Atlantic, "when nonviolence begins halfway through the war with

\footnotetext{
93 Wink, 67.

94 Crimethinc., "Reflections on the Ferguson Uprising," I 2 August 20 I 5. Available from http://theanarchistlibrary.org/library/crimethinc-reflections-on-the-ferguson-uprising.pdf (accessed 29 November 201 5 ).

95 According to Columbia University linguist John McWhorter, "the truth is that thug today is a nominally polite way of using the N-word." For the full interview, see: http://www.npr.org/2015/04/30/403362626/ the-racially-charged-meaning-behind-the-word-thug
} 
the aggressor calling time out, it exposes itself as a ruse." ${ }^{96}$ In other words, nonviolence does in fact become a means of control and repression in this case, which is a large part of Gelderloos' worry cited above. As Coates concludes his article:

When nonviolence is preached by the representatives of the state, while the state doles out heaps of violence to its citizens, it reveals itself to be a con. And none of this can mean that rioting or violence is 'correct' or 'wise,' any more than a forest fire can be 'correct' or 'wise.' Wisdom isn't the point tonight. Disrespect is. In this case, disrespect for the hollow law and failed order that so regularly disrespects the community. ${ }^{97}$

This echoes Gordon's point discussed above. Nonviolence is called for by the greatest perpetrators of violence as a means to ensure that the disobedient group remains powerless to effect real change. If, on the other hand, the disobedient group does not adopt nonviolence, and violence is perhaps escalated even further, the state will simply label the actions 'illegal,' 'illegitimate,' and most importantly - 'violent,' and doing so provides an alternative method of maintaining control. We thus face a kind of catch-22. Both violence and nonviolence can be manipulated in favour of the interests of the powerful.

What all of this means, I think, is that there are no simple answers. Every situation is different and must be assessed on an individual basis. If windows are broken and nonviolence is called for, perhaps it is time for both parties involved to sit down and attempt to bridge the contentious divide through dialogue. Or, perhaps it is time to engage in further civil disobedience. I maintain, however, that once violence against persons is resorted to, the status quo has been reaffirmed and the cycle of violence re-entered. Violence against persons is seen as perfectly valid in the hands of the powerful, and, as Bart de Ligt writes, "it is the task of the social revolution to go beyond this violence and to

${ }_{96}$ Ta-Nehisi Coates, "Nonviolence as Compliance," The Atlantic, available from http://www.theatlantic.com/politics/archive/201 5/04/nonviolenceas-compliance/391640/ (accessed 29 November 201 5 ).

97 Ibid. 
emancipate itself from it." ${ }_{98}^{8}$ Otherwise we remain captive to the instrumental thinking that allows us to see persons as expendable and the might-is-right logic that offers justifications for violence as a legitimate response to dissent and disagreement.

While I do not agree with those pacifists - Ellul and Tolstoy among them ${ }^{99}$ - who argue that the violence of the oppressed against the oppressor is the same as the violence of the oppressor against the oppressed, I do argue that violence against persons must always be avoided insofar as adopting it opens the road for oppressive institutions to do the same and even claim that they are the party who can legitimately do so in order to restore order and minimise the violence which is spinning out of control.

This may be unsatisfying to many who want to see immediate, drastic change, and recognize that violence is often - if not always - the means for realising such change. But as Yoder writes, "Violence is always, apparently, the shortest and surest way . . . [a]nd in the long run that appearance always deceives." ${ }^{\circ 00}$ It does not create a new world, it does not change our relationships, and it does not address the problem of having such a violent society in the first place. What the use of violence does do, according to Christian anarchists, is affirm the superiority of violence over love - to, in other words, deny the possibility of overcoming violence with love. And while it is true that nonviolence will not always give us the quick results that violence promises, as Walter Wink writes, "[t]he issue . . is not just which works better, but which fails better. While a nonviolent strategy also does not always 'work' in terms of pre-set goals - though in another sense it always 'works' - at least the casualties and destruction are far less severe." ${ }^{\text {ior }}$

All of this comes back to prefiguration. If we want a nonviolent, non-coercive world, we would be miscalculating to hope to achieve it through violence and coercion. For "it is impossible,"

$9^{8}$ Bart de Ligt, The Conquest of Violence: An Essay on War and Revolution, (Winchester: Pluto Press, I989), I68.

99 See Ellul, Violence, 97.

to John Howard Yoder, quoted in Christoyannopoulos, Christian Anarchism: A Political Commentary On the Gospel, 40.

го Wink, 54 . 
writes Bart de Ligt, "to educate people in liberty by force, just as it is impossible to breathe by coal gas." ${ }^{\circ 2}$

\section{Conclusion}

Christ calls his followers to participate in the new kingdom that he is inaugurating - the Unkingdom, which operates in every way counter to the way the worldly kingdoms operate. This, I think, is one of the most powerful ideas that Christ and his followers can offer to anarchism. I maintain that Christ calls his followers to live according to the Unkingdom right now, to not be conformed to the ways of the world, as Paul says, but to live otherwise. At no point does Jesus say that this will be easy - indeed, he explicitly says the opposite. And it must surely be admitted that, according to worldly standards of practicality, living according to the Unkingdom could not possibly be more impractical. But, in another way, such living is supremely practical insofar as it is the only way to realize the Unkingdom. In other words, we must live according to the paradoxically now-and-to-come Unkingdom, both because it is here and because it is still to come. Adopting the radical nonviolence that Jesus teaches in the Sermon on the Mount is one of the most important ways that we can do so. It may seem crazy at first blush - and, again, it is crazy from the standpoint of maintaining the status quo - but it is in fact the only way to escape the cycle of violence and to prefigure a more loving, peaceful, and just society, an anarchist society.

I submit that if we take the Sermon on the Mount as a daily guide for transforming ourselves as well as our relationships with others - viz., as a guide for prefiguring the Unkingdom that is where the deepest and longest lasting change will begin. As Tolstoy writes, "in our world everybody thinks of changing humanity, and nobody thinks of changing himself [sic]." ${ }^{\text {I03 }}$ As social creatures, to change ourselves is at the same time to change our relationships with others. And - going back to Landauer - it

\footnotetext{
${ }^{102}$ De Ligt, 72.

ro3 Leo Tolstoy, "On Anarchy," in Government is Violence: Essays on Anarchism and Pacifism, edited by David Stephens, (London: Phoenix Press, I990), 70.
} 
is through changing our relationships with others, through countering the violence, hatred, and greed of the present world with love, forgiveness, and nonviolence, that we will build a new world in the shell of the old.

\section{References}

Alexis-Baker, Andy, "Violence, Nonviolence and the Temple Incident in John 2:I3-I 5." In Biblical Interpretation 20, 201 2. 73-96.

Camp, Lee C. "What About Romans I 3 : 'Let Every Soul Be Subject'?” In A Faith Not Worth Fighting For: Addressing Commonly Asked Questions About Christian Nonviolence, edited by Tripp York and Justin Bronson Barringer, I40-I 53.

Caputo, John D. On Religion. London \& New York: Routledge, 2001 .

. "On the Event in Christianity." Available from https://www. youtube.com/watch?v=R2nq8baHDFY. Accessed 29 November 2015 .

- "Spectral Hermeneutics." In After the Death of God, edited by Jeffrey W. Robbins, 47-85. New York: Columbia University Press, 2007.

What Would Jesus Deconstruct? The Good News of Postmodernity for the Church, Grand Rapids: Baker Academic, 2007.

Christoyannopoulos, Alexandre. Christian Anarchism: A Political Commentary On the Gospel. Exeter: Imprint Academic, 20 I I.

Churchill, Ward. Pacifism As Pathology. Oakland: AK Press, 2007.

Coates, Ta-Nehisi. "Nonviolence as Compliance." The Atlantic. 27 April 2015. Available from http://www.theatlantic.com/politics/ archive/20I 5/04/nonviolence-as-compliance/39 I 640/. Accessed 29 November 2015.

Crimethinc. "Reflections on the Ferguson Uprising." I 2 August 20 I 5. Available from http://theanarchistlibrary.org/library/crimethincreflections-on-the-ferguson-uprising.pdf. Accessed 29 November 2015 . 
Crockett, Clayton. Radical Political Theology. New York: Columbia University Press, 20I I.

Crugnale, James. "UC Davis Police Pepper Spray Student Occupy Protestors, University Investigating Incident." Mediaite. I9 November 20I I. Available from https://www.mediaite.com/online/ uc-davis-police-pepper-spray-student-occupy-protestors-universityinvestigating-incident/. Accessed 3 I July 20 I 5.

Daugherty, Kevin. "Romans I 3 and the State." MennoNerds. 25 January 20I4. Available from http://mennonerds.com/romans-I3and-the-state/. Accessed 3 August 2015.

De Ligt, Bart. The Conquest of Violence: An Essay on War and Revolution. Winchester: Pluto Press, I989.

De Waal, The Age of Empathy: Nature's Lessons for a Kinder Society. New York: Three Rivers Press, 2009.

Dear, John. “Didn't Jesus Overturn Tables and Chase People Out of the Temple With a Whip?" In A Faith Not Worth Fighting For: Addressing Commonly Asked Questions About Christian Nonviolence, edited by Tripp York and Justin Bronson Barringer, I 84-I9I.

Ehrman, Bart D. How Jesus Became God: The Exaltation of a Jewish Preacher from Galilee. New York: HarperOne, 2014.

Ellul, Jacques. Anarchy and Christianity. Translated by Geoffrey W. Bromiley. Eugene: Wipf \& Stock, 20I I.

- Violence: Reflections From A Christian Perspective. Translated by Cecilia Gaul Kings. Eugene: Wipf \& Stock, 20 I I.

Franks, Benjamin. "The Direct Action Ethic." In Anarchism: A Documentary History of Libertarian Ideas, Volume Three: The New Anarchism (I974-20I2), edited by Robert Graham, 85-89.

Gelderloos, Peter. How Nonviolence Protects the State. Brooklyn: South End Press, 2007.

Goldman, Emma. Anarchism and Other Essays (Second, Revised Edition). New York/London: Mother Earth Publishing Association, I9I I. Available from https://theanarchistlibrary.org/library/emma-goldman-anarchism-and-other-essays\#toc4. Accessed I7 May 2018 . 
Graeber, David. "Caring Too Much. That's the Curse of the Working Classes." The Guardian. 26 March 20I4. Available from http:// www.theguardian.com/commentisfree/20I $4 / \mathrm{mar} / 26 /$ caring-curse-working-class-austerity-solidarity-scourge? $\mathrm{CMP}=\mathrm{fb}$ gu. Accessed 3 I July 2015.

Graham, Robert, ed. Anarchism: A Documentary History of Libertarian Ideas, Volume One: From Anarchy to Anarchism (300CE to I939). Montreal/New York/London: Black Rose Books, 2005.

. Anarchism: A Documentary History of Libertarian Ideas, Volume Two: The Emergence of the New Anarchism (I939-1977). Montreal/New York/London: Black Rose Books, 2009.

Anarchism: A Documentary History of Libertarian Ideas, Volume Three: The New Anarchism (I974-20 I 2). Montreal/New York/London: Black Rose Books, 20I3.

Grave, Jean. "Means and Ends." In Anarchism: A Documentary History of Libertarian Ideas, Volume One: From Anarchy to Anarchism (300CE to I939), edited by Robert Graham, I 56-I 57.

Hebden, Keith. Seeking Justice: The Radical Compassion of Jesus. Washington: Circle Books, 2013.

Jun, Nathan J. Anarchism and Political Modernity. New York: Continuum, $20 \mathrm{I} 2$.

Kearney, Richard. Anatheism: Returning to God After God. New York: Columbia University Press, 20 I I.

. Debates in Continental Philosophy: Conversations with Contemporary Thinkers. New York: Fordham University Press, 2004.

—. "Anatheism." By Josef Gustafsson and David Capener. Freestyle Christianity. I7 February 20I6. Available from http:// www.freestylechristianity.se/podcast/richard-kearney-anatheism/. Accessed 3 I May 2016.

- The God Who May Be. Bloomington \& Indianapolis: Indiana University Press, 200I.

- "Theorizing the Gift." In Debates in Continental Philosophy: Conversations with Contemporary Thinkers, edited by Richard Kearney, 284-304. 
Kierkegaard, Søren. Works of Love. Translated by Howard and Edna Hong. New York: Harper Perennial, 2009.

Kinna, Ruth. Anarchism: A Beginner's Guide. Oxford: Oneworld Publications, 2005 .

Kouddous, Sharif Abdel. "Palestinians Engaged in Nonviolent Protest. Israel Responded With a Massacre." The Nation. I7 May 2018. Available from https://www.thenation.com/article/palestiniansengaged-in-nonviolent-protest-israel-responded-with-a-massacre/. Accessed I7 May 2018.

Kropotkin, Peter. "Anarchist Communism: Its Basis and Principles." In Anarchism: A Collection of Revolutionary Writings, edited by Roger N. Baldwin, 44-78. Mineola: Dover Publications, Inc., 2002. Publications, Inc., 2006.

Landauer, Gustav. "Destroying the State By Creating Socialism." In Anarchism: A Documentary History of Libertarian Ideas, Volume One: From Anarchy to Anarchism (300CE to I939), edited by Robert Graham, I64-I65.

Long, D. Stephen. "What About the Protection of Third-Party Innocents? On Letting Your Neighbors Die.” In A Faith Not Worth Fighting For: Addressing Commonly Asked Questions About Christian Nonviolence, edited by Tripp York and Justin Bronson Barringer, I 8-30.

Malatesta, Errico. "Violence as a Social Factor." In Anarchism: A Documentary History of Libertarian Ideas, Volume One: From Anarchy to Anarchism (300CE to 1939), edited by Robert Graham, I60-163.

McWhorter, John. "The Racially Charged Meaning Behind the Word 'Thug." Interview by Melissa Block. NPR. 30 April 2015. Available from http://www.npr.org/20I 5/04/30/403362626/theracially-charged-meaning-behind-the-word-thug. Accessed 27 May 2016.

Minyi, Chu. "Universal Revolution.” In Anarchism: A Documentary History of Libertarian Ideas, Volume One: From Anarchy to Anarchism (300CE to I 939), edited by Robert Graham, 34I-347. 
Albert Meltzer. Anarchism: Arguments For \& Against $\left(6^{\text {th }}\right.$ Second Revised Edition). San Fransisco: AK Press, I996.

The Real News Network. "IDF Prepares to Kill More Peaceful Protesters in Gaza on Friday." I7 May 2018. Available from https://therealnews.com/stories/idf-prepares-to-kill-more-peacefulprotesters-in-gaza-on-friday. Accessed I7 May 20 I 8.

Ricoeur, Paul. "Philosophical and Biblical Hermeneutics." In From Text to Action: Essays in Hermeneutics, II, translated by Kathleen Blamey, 89-IOI. Evanston: Northwestern University Press, I99I.

Rodkey, Christopher. "When a Radical Theologian gets in the Pulpit." Interview by Tripp Fuller. Homebrewed Christianity, I 8 July 20I5. Available from http://homebrewedchristianity. com/20 I 5/07/I 8/when-a-radical-theologian-gets-in-the-pulpit/. Accessed I 5 November 2015.

The Green Bible. San Francisco: HarperOne, 2008.

Tolstoy, Leo. My Religion - What I Believe. Translated by Huntington Smith. Guildford: White Crow Books, 2009.

-. "On Anarchy." In Government is Violence: Essays on Anarchism and Pacifism, edited by David Stephens, translated by Vladimir Tchertkoff, 67-70. London: Phoenix Press, I990. . "The Slavery of Our Times." In Government is Violence: Essays on Anarchism and Pacifism, edited by David Stephens, translated by Aylmer Maude, I I I-I 55. London: Phoenix Press, I990.

Van Steenwyk, Mark. The UNkingdom of God: Embracing the Subversive Power of Repentance. Downers Grove: InterVarsity Press, 2013.

Walter, Nicolas. “Direct Action and the New Pacifism.” In Anarchism: A Documentary History of Libertarian Ideas, Volume Two: The Emergence of the New Anarchism (1939-1977), edited by Robert Graham, I96-205.

Willems, Kurt. "Nonviolence Io I - Resistance is Futile... or the Meaning

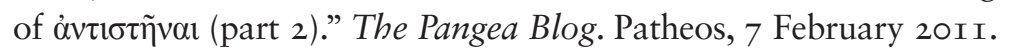
Accessed 6 May 20I3. 
Wink, Walter. Jesus and Nonviolence: A Third Way. Minneapolis: Fortress Press, 2003.

Yoder, John Howard. The Politics of Jesus. $2^{\text {nd }}$ ed. Grand Rapids: William B. Eerdmans

Publishing Company, I994.

York, Tripp and Barringer, Justin Bronson, eds. A Faith Not Worth Fighting For: Addressing Commonly Asked Questions About Christian Nonviolence. Eugene: Cascade Books, $20 \mathrm{I} 2$. 